\title{
Evaluasi Pelatihan Pencegahan dan Penanggulangan Kebakaran di Lingkungan Rumah Tangga
}

\author{
Casban$^{1}$, Umi Marfuah ${ }^{2}$, Didi Sunardi ${ }^{3}$, Aria Purnamasari Dewi ${ }^{4}$ \\ 1,2,3,4 Teknik Industri, Fakultas Teknik, Universitas Muhammadiyah Jakarta \\ Jalan Cempaka Putih Tengah No. 27 Jakarta 10510
}

E-mail : casban@ftumj.ac.id;, umi.marfuah@ftumj.ac.id;, didi.sunardi@ftumj.ac.id;, ariya.purnamasari@ftumj.ac.id

\begin{abstract}
Abstrak
Peristiwa kebakaran dapat terjadi secara tiba-tiba, sehingga diperlukan pemberdayaan masyarakat untuk meminimalisir faktor penyebab kebakaran. Upaya tindakan pencegahan kebakaran dilakukan melalui kegiatan pengabdian masyarakat dengan memberikan pelatihan pencegahan dan penanggulangan kebakaran. Tujuan penelitian untuk mengetahui tingkat keberhasilan dan mengukur implementasi kegiatan pelatihan berdasarkan evaluasi proses, evaluasi hasil dan evaluasi dampak. Desain penelitian sebagai penelitian evaluasi dengan menggunakan model Result Based Management (RBM) melalui pendekatan penelitian deskriptif kualitatif. Mitra kerjama dalam kegiatan pengabdian masyarakat adalah warga RT 08 RW 09 Kelurahan Kebon Pala Kecamatan Makasar Jakarta Timur. Waktu pelaksanaan pada tanggal 4 Agustus 2020. Teknik pengumpulan data dilakukan dengan observasi, wawancara, kuesioner, studi dokumentasi dan kajian literatur. Metode analisis menggunakan model RBM berdasarkan aspek sumber daya, kegiatan, produk, hasil dan dampak. Berdasarkan hasil analisis dapat disimpulkan yaitu aspek evaluasi proses dapat diketahui bahwa metode pelaksanaan kegiatan pelatihan dilakukan secara teori dan praktek mendapatkan respon positif dari mitra yang mempunyai keinginan untuk mempelajari materi. Aspek evaluasi hasil dapat diketahui bahwa kegiatan pelatihan dapat mendorong sikap kepedulian mitra untuk melakukan tindakan pencegahan kebakaran dalam lingkungan masyarakat. Aspek evaluasi dampak dapat diketahui bahwa kegiatan pelatihan dapat memberikan perubahan sikap dari mitra yang sudah mempraktekkan materi pelatihan dan menyiapkan peralatan pencegahan kebakaran.
\end{abstract}

Kata Kunci : evaluasi, pencegahan kebakaran dan Result Based Management.

\section{PENDAHULUAN}

Peristiwa kebakaran dapat terjadi kapan saja tanpa diduga dan tidak disengaja yang dapat menghanguskan bangunan rumah, tanaman dan sebagainya yang akan mengakibatkan kerugian terhadap kehilangan harta benda dan dapat merenggut nyawa manusia. Kebakaran berasal dari api kecil atau besar yang dapat merugikan baik secara ekonomi dan sosial (Dewi, 2013). Besarnya nyala api pada kondisi kebakaran tidak dapat dikendalikan dan diluar keinginan manusia (Ramli, 2010). Penyebab kebakaran yang sering terjadi di lingkungan rumah bersumber dari hubungan arus pendek atau konsleting listrik dan kebocoran gas elpiji. Bencana kebakaran dari faktor alam yaitu musim kemarau yang dapat meningkatkan potensi terjadinya kebakaran karena kondisi yang kering dengan suhu udara cukup panas pada siang hari dan dapat terus meningkat terkena panas dari sinar matahari serta adanya perilaku masyarakat yang membakar sampah secara sembarangan dapat berpotensi menimbulkan kebakaran.

Data statistik kebakaran yang terjadi di Jakarta di tahun 2019, sebanyak 1.355 kasus dengan

$$
\text { Lingkungan Hidup dan Kebencanaan }
$$


penyebab kebakaran dari konsleting listrik sebanyak 557 kasus, kompor gas sebanyak 102 kasus, puntung rokok sebanyak 51 kasus, dan sisanya penyebab lainnya sebanyak 645 kasus ( sumber : https://www.jakartafire.net/statistic). Dampak dari bahaya kebakaran dapat disebabkan karena adanya nyala api yang tidak terkendali sehingga dapat mengancam keselamatan jiwa maupun harta benda (Sucipto, 2014). Untuk mengurangi kerugian yang diakibatkan dari bahaya kebakaran maka bangunan harus dilengkapi sistem proteksi kebakaran baik secara aktif maupun pasif dengan kelengkapan sarana penyelamatan (Hidayat, dkk, 2017).

Secara umum, sikap kepedulian dan kesiapsiagaan dari masyarakat terhadap keselamatan lingkungan rumah dari bahaya kebakaran masih tidak sebanding dengan kepedulian terhadap peningkatan kebutuhan hidup sehari-hari (Furi, 2012). Langkah pencegahan yang dapat dilakukan dengan sikap kesiapsiagaan dari masyarakat dalam menghadapi kebakaran terutama untuk menjaga keselamatan nyawa sehingga menjadi hal yang penting bagi setiap orang untuk memiliki keterampilan evakuasi secara mandiri (Eni, dkk 2017). Untuk meminimalisir faktor penyebab terjadinya kebakaran rumah diperlukan pemberdayaan masyarakat sehingga dapat melakukan tindakan pencegahan dan penanggulangan kebakaran dilingkungan rumah sebagai upaya kesiapan masyarakat dengan mengembangkan sumber daya, kesempatan, pengetahuan, dan keahlian (Anwas, 2014).

Upaya tindakan pencegahan kebakaran dilakukan oleh Tim dosen jurusan Teknik Industri Universitas Muhammadiyah Jakarta dengan memberikan pelatihan pencegahan dan penanggulangan kebakaran di lingkungan rumah tangga. Tujuan pelatihan dalam kegiatan pengabdian masyarakat adalah untuk memberikan pengetahuan tentang faktor penyebab terjadinya kebakaran dan tindakan pencegahannya, sehingga masyarakat dapat mengimplementasikan dalam kehidupan sehari-hari untuk menghindari terjadinya kebakaran sedangkan manfaat jangka panjang dari kegiatan pelatihan adalah untuk mendorong sikap kepedulian dalam tindakan pencegahan kebakaran dalam komunitas lingkungan masyarakat.

Pelaksanaan dalam kegiatan pelatihan pencegahan dan penanggulangan kebakaran meliputi presentasi yang dilakukan dengan memberikan materi pelatihan untuk menambah pengetahuan dan wawasan tentang bahaya kebakaran dan tindakan penanggulangannya. Dalam kegiatan praktek dibimbing oleh instruktur dari suku dinas kebakaran Jakarta Timur untuk memberikan pelatihan praktek tentang potensi bahaya kebakaran yang sering terjadi dalam kegiatan sehari-hari dirumah terutama yang berkaitan dengan kegiatan memasak di dapur. Peninjauan hasil pelatihan dilakukan oleh instruktur dan tim dosen untuk melakukan evaluasi kegiatan pelatihan yang dilakukan mulai dari presentasi materi dan kegiatan praktek memadamkan api.

Manfaat dari kegiatan pelatihan pencegahan dan penanganan kebakaran yaitu 1) Mitra memperoleh pengetahuan mengenai sumber penyebab kebakaran yang sering terjadi di lingkungan rumah; 2) Mitra sudah dapat melakukan tindakan penanggulangan untuk mengurangi faktor penyebab terjadinya kebakaran terutama yang berasal dari bahaya konsleting listrik, pemakaian kompor gas, dan faktor kelalaian dalam menggunakan peralatan yang ada di rumah.

Kegiatan pelatihan perlu dilakukan evaluasi untuk mengetahui tingkat keberhasilan pelatihan pencegahan dan penanggulangan kebakaran dapat memberikan manfaat untuk melakukan tindakan pencegahan dan penanggulangan kebakaran serta dapat mendorong sikap kepedulian dan kemandirian terhadap penanggulangan kebakaran dalam komunitas lingkungan masyarakat. Evaluasi kegiatan pelatihan digunakan untuk mengukur sejauh mana implementasi materi pelatihan dapat meningkatkan pengetahuan, kemampuan dan keterampilan yang dimiliki oleh mitra untuk melakukan pencegahan dan penanggulangan kebakaran dalam aktivitas kehidupan sehari-hari.

Berdasarkan permasalahan yang sudah dijelaskan diatas maka tujuan yang akan dikaji dalam penelitian ini yaitu untuk mengetahui tingkat keberhasilan dan mengukur implementasi kegiatan pelatihan pencegahan dan penanggulangan kebakaran di lingkungan rumah tangga yang sudah dilakukan dalam kegiatan pengabdian masyarakat berdasarkan aspek evaluasi proses, evaluasi hasil dan evaluasi dampak.

Sumber penyebab kebakaran pada rumah lebih banyak berasal dari korsleting listrik yang dipengaruhi faktor kelalaian dan masyarakat masih 
menganggap kurang penting untuk memahami bahaya dari penggunaan peralatan elektronik dan instalasi listrik yang tidak standar (Amat, dkk, 2018). Pemasangan instalasi listrik yang tidak standar menjadi faktor penyebab kebakaran yang paling tinggi menurut pendapat masyarakat (Yunita, $\mathrm{dkk}$, 2016). Pemahaman masyarakat yang masih kurang tentang sumber bahaya kebakaran yang diakibat adanya tindakan pencantolan listrik dan kesalahan instalasi kabel listrik di rumah yang berpotensi menimbulkan adanya arus pendek (Ranti, 2018), sehingga untuk pencegahan bahaya kebakaran di rumah maka diperlukan penggunaan sensor yang dapat mendeteksi kemungkinan potensi kebakaran secara akurat (Irfanul, dkk 2019).

Pelatihan pencegahan dan penanggulangan kebakaran dapat dilakukan oleh kalangan akademis sebagai upaya untuk meningkatkan pengetahuan masyarakat atau minimal mengingatkan kembali mengenai perilaku aman melalui edukasi dan sosialisasi baik secara langsung ataupun berbagai media untuk mencegah terjadinya kebakaran di rumah (Ani, dkk,2018). Sosialisasi perlu dilakukan untuk memberikan pengetahuan dalam penggunaan peralatan listrik yang baik dan benar bagi masyarakat dapat memberi dampak positif dan memberi nilai yang besar (Tasdik, dkk, 2018).

Kegiatan pelatihan pencegahan dan penanggulangan kebakaran di lingkungan rumah tangga yang sudah dilakukan dalam kegiatan pengabdian masyarakat perlu dilakukan evaluasi. Fungsi evaluasi dapat memberikan informasi yang valid mengenai kinerja kebijakan, program dan kegiatan yang berkaitan seberapa jauh mana kebutuhan, nilai dan kesempatan telah tercapai sehingga dapat diketahui pencapaian tujuan, sasaran dan target, serta dapat mengaplikasikan metode analisis kebijakan termasuk perumusan masalah dan rekomendasinya (Tini, dkk, 2015). Evaluasi berfungsi sebagai alat verifikasi apakah program dapat berjalan sesuai dengan rencana dengan menetapkan indikator dalam evaluasi sebagai ukuran kinerja, karena keberhasilan dan kegagalan dapat dikur dengan menggunakan indikator kinerja yang relevan sesuai dengan tingkatannya yaitu impact, outcome, output dan input (Dedi, 2009).

Model evaluasi yang digunakan dalam penelitian ini melalui Result Based Management
(RBM) sebagai strategi manajemen yang digunakan untuk memberikan kontribusi secara langsung maupun tidak langsung terhadap hasil yang diinginkan dalam suatu program (United Nations Development Programme, 2009). Model evaluasi RBM menggunakan indikator dari hasil yang dapat dicapai sebagai ukuran keberhasilan dengan mengkaji berbagai permasalahan dalam mencapai tujuan dan sasaran program yang sudah ditetapkan.

Siklus evaluasi model RBM dibagi menjadi tiga bagian yaitu tahap planning, tahap monitoring dan tahap evaluation. Dalam tahap planning mendefinisikan pandangan bersama tentang program yang ada serta mendefinisikan hasil yang diinginkan, mencakup berbagai tahapan kegiatan yang akan dilakukan untuk mendapatkan hasil yang akan dicapai. Langkah perencanaan digunakan sebagai dasar untuk mengukur tahapan kerangka RMB dapat dilaksanakan seusai tujuan yang sudah ditetapkan. Tahap monitoring dilakukan untuk mengetahui pelaksanaan kegiatan dan manajemen tindakan yang akan dilakukan dalam kegiatan pelatihan. Tahap evaluation dilakukan untuk mendapatkan hasil pelaksanaan kegiatan apakah sudah sesuai dengan tahapan perencanaan yang sudah dibuat sebelumnya, sehingga dapat membuat keputusan berdasarkan tujuan yang ditetapkan.

Evaluasi dengan model RBM yang digunakan dalam penelitian ini berdasarkan evaluasi proses, evaluasi hasil dan evalusi dampak. Kegunaan evaluasi proses untuk mengetahui program pelatihan dari proses persiapan materi, bahan, peralatan, dan pelaksanaan praktek dapat dilakukan dengan baik sesuai dengan tujuan yang akan dicapai. Kegunaan evaluasi hasil untuk mengukur program pelatihan dapat memberikan pengetahuan yang dapat diterapkan oleh masyarakat dalam meminimalisasi potensi bahaya kebakaran. Kegunaan evaluasi dampak untuk mengetahui program pelatihan dapat memberikan perubahan yang dapat memberikan dampak positif bagi masyarakat yang mempunyai kepedulian terhadap potensi bahaya kebakaran dilingkungan rumah. Hasil evaluasi digunakan untuk membuat rekomendasi keberlanjutan program pelatihan dihentikan atau diteruskan. Sesuai dengan tujuan program pelatihan yang sudah ditetapkan.

\section{METODE}

Lingkungan Hidup dan Kebencanaan

472 
Desain penelitian menggunakan penelitian evaluasi melalui pendekatan deskripsi kualitatif untuk mengukur pelaksanaan kegiatan pelatihan berjalan secara efektif atau tidak dibandingkan dengan tujuan atau sasaran yang sudah ditetapkan sehingga dapat membuat keputusan terhadap keberlanjutan program yang sudah dilaksanakan dapat diteruskan atau dihentikan (Sugiyono, 2013). Data evaluasi kualitatif dalam tahapan awalnya masih belum diolah, sehingga diperlukan pengumpulan data yang dilakukan melalui kegiatan pengamatan langsung dilapangan, wawancara dan dokumentasi (Michael, 2006).

Mitra kerjama dalam kegiatan pengabdian masyarakat adalah warga RT 08 RW 09 Kelurahan Kebon Pala Kecamatan Makasar Jakarta Timur. Waktu pelaksanaan kegiatan dilakukan pada tanggal 4 Agustus 2020. Sasaran yang akan dicapai dari kegiatan pelatihan pencegahan dan penanggulangan kebakaran yang sudah dilakukan dalam kegiatan pengabdian masyarakat adalah mitra mempunyai pengetahuan untuk meminimalisir terjadinya kebakaran dalam lingkungan rumah dan mempunyai tingkat kepedulian dan sikap kesiapsiagaan untuk penanggulangan kebakaran

Teknik pengumpulan data dilakukan melalui (a) Observasi yaitu melakukan kegiatan pengamatan secara langsung di lapangan untuk mengetahui hasil dan dampak dari kegiatan pelatihan. (b) Wawancara yaitu melakukan wawancara dengan mengajukan pertanyaan terbuka, mendengarkan dan menindaklanjuti dengan pertanyaan tambahan yang digunakan untuk menggali data atau informasi yang lebih lengkap dan secara mendetail. (c) Kuesioner yaitu berupa 9 pertanyaan dengan jawaban tertutup yaitu dengan memberikan jawaban ya atau tidak dan 1 pertanyaan dengan jawaban terbuka yang digunakan untuk mendapatkan umpan balik berupa saran atau masukan yang diberikan oleh mitra. (d) Dokumentasi yaitu untuk menyajikan informasi tentang kegiatan pelatihan yang sudah dilakukan yang digunakan untuk melengkapi dokumen administrasi. (e) Studi kepustakaan yaitu mempelajari ilmu dari literatur yang memiliki keterkaitan dengan permasalahan yang akan dikaji dalam penelitian, sehingga mendapatkan solusi terhadap pemecahan permasalahan.

Instrumen penelitian yang digunakan berupa kuesioner yang berisi sejumlah pertanyaan untuk mendapatkan data atau informasi mengenai evaluasi kegiatan pelatihan pencegahan kebakaran berdasarkan evaluasi proses, evaluasi hasil dan evalusi dampak, dengan kisi-kisi pada tabel berikut.

Tabel 1. Kis-kisi instrumen penelitian

\begin{tabular}{|c|c|c|c|}
\hline No & Aspek & Dimensi & Indikator \\
\hline 1 & $\begin{array}{l}\text { Evaluasi } \\
\text { proses }\end{array}$ & $\begin{array}{l}\text { - Sumber daya } \\
\text { manusia } \\
\text { - Metode } \\
\text { penyampaian } \\
\text { - Kegiatan } \\
\text { praktek }\end{array}$ & $\begin{array}{l}\text { - Kehadiran peserta } \\
\text { pelatihan } \\
\text { - Materi mudah } \\
\text { dipahami } \\
\text { - Melakukan } \\
\text { simulasi }\end{array}$ \\
\hline 2 & $\begin{array}{l}\text { Evaluasi } \\
\text { hasil }\end{array}$ & $\begin{array}{l}\text { - Pengetahuan } \\
\text { bahaya } \\
\text { kebakaran } \\
\text { - Keterampilan } \\
\text { pencegahan } \\
\text { kebakaran }\end{array}$ & $\begin{array}{l}\text { - Peningkatan } \\
\text { wawasan dan } \\
\text { pengetahuan } \\
\text { - Peningkatan } \\
\text { keterampilan }\end{array}$ \\
\hline \multirow[t]{2}{*}{3} & $\begin{array}{l}\text { Evaluasi } \\
\text { dampak }\end{array}$ & $\begin{array}{l}\text { - Kepedulian } \\
\text { pencegahan }\end{array}$ & $\begin{array}{l}\text { - Menumbuhkan } \\
\text { sikap kepedulian }\end{array}$ \\
\hline & & $\begin{array}{l}\text { kebakaran } \\
\text { - Kesiapsiagaan } \\
\text { tanggap darurat }\end{array}$ & $\begin{array}{l}\text { - Menumbuhkan } \\
\text { sikap siap siaga }\end{array}$ \\
\hline
\end{tabular}

Pemeriksaan tingkat keabsahan data dilakukan melalui triangulasi yang terdiri dari (a) Triangulasi sumber digunakan untuk menentukan tingkat validitas dari data dan informasi yang sudah diperoleh dari berbagai sumber. (b) Triangulasi teknik dengan melakukan pemeriksaan keabsahan data dengan menggunakan teknik yang berbeda terhadap sumber data yang sama. (c) Triangulasi waktu dengan menggunakan teknik pengumpulan data yang berbeda dan dilakukan dalam periode waktu yang berlainan.

Tahapan pengolahan data dilakukan melalui model Result Based Management (RBM) sebagai cara untuk mengevaluasi program pelatihan pencegahan dan penanggulangan kebakaran di lingkungan rumah tangga, berdasarkan 3 jenis aspek evaluasi yaitu evaluasi proses, evaluasi hasil, dan evaluasi dampak untuk melihat keberhasilan suatu program dari aspek (a) Input yang mencakup aspek

sumber daya manusia, material, bahan dan biaya yang diperlukan untuk melakukan kegiatan

$$
\text { Lingkungan Hidup dan Kebencanaan }
$$


pelatihan. (b) Activities yaitu tindakan yang dilakukan dalam memberikan pelatihan sehingga dapat menghasilkan keluaran yang spesifik. (c) Outputs berupa materi pelatihan yang disampaikan dalam kegiatan pelatihan baik secara teori dan kegiatan praktek. (d) Result sebagai kondisi yang dapat memberikan perubahan yang signifikan bagi mitra baik dari aspek pengetahuan, keterampilan dan keahlian dalam pencegahan kebakaran. (e) Impact berupa hasil tertinggi yang dapat dihasilkan dari kegiatan pelatihan yang dapat diketahui dengan melihat adanya perubahan dari segi efek positif atau negatif yang sudah ditunjukkan oleh mitra.

Tahapan analisa dan pembahasan dilakukan untuk mengetahui tingkat keberhasilan kegiatan pelatihan berdasarkan aspek evaluasi yang mencakup (a) Evaluasi proses untuk mengetahui pelaksanaan kegiatan sesuai tujuan yang sudah ditetapkan dari aspek sumber daya manusia, metode penyampaian materi dan kegiatan praktek. (b) Evaluasi hasil untuk menilai kegiatan pelatihan dapat meningkatkan pengetahuan mengidentifikasi potensi bahaya kebakaran dan keterampilan dalam penanggulangan kebakaran. (c) Evaluasi dampak digunakan untuk melihat perubahan dari segi efek positif atau negatif dari mitra terhadap sikap kepedulian dalam pencegahan kebakaran dan kesiapsiagaan dalam kondisi tanggap darurat.

\section{HASIL DAN PEMBAHASAN}

Pengumpulan data penelitian dilakukan melalui kuesioner yang diberikan kepada mitra yang sudah mendapatkan materi pelatihan. Data mitra yang mengisi kuesioner berjumlah 15 orang, berdasarkan range umur pada tabel berikut.

Tabel 2. Data mitra berdasarkan range umur

\begin{tabular}{cccc}
\hline No & $\begin{array}{c}\text { Range Umur } \\
\text { (tahun) }\end{array}$ & $\begin{array}{c}\text { Jumlah } \\
\text { (orang) }\end{array}$ & $\begin{array}{c}\text { Presentase } \\
(\%)\end{array}$ \\
\hline 1 & $30-39$ & 3 & 20.0 \\
2 & $40-49$ & 2 & 13.3 \\
3 & $50-59$ & 6 & 40.0 \\
4 & $60-69$ & 4 & 26.7 \\
& Jumlah & 15 & 100 \\
\hline
\end{tabular}

Berdasarkan data umur dapat diketahui yang paling tinggi adalah range umur $50-59$ tahun dan $60-69$ tahun, hal ini dapat mengindikasikan bahwa mitra dalam kelompok ini adalah warga masyarakat yang sudah memasuki masa pensiun, yang lebih banyak berada dilingkungan rumah. Sedangkan mitra dalam kelompok yang lain adalah warga masyarakat yang masih usia produktif dengan berbagai aktivitas baik pekerjaan dirumah maupun di tempat kerja. tabel berikut.

Data mitra berdasarkan jenis pekerjaan pada

Tabel 3. Data mitra berdasarkan jenis pekerjaan

\begin{tabular}{cccc}
\hline No & Pekerjaan & $\begin{array}{c}\text { Jumlah } \\
\text { (orang) }\end{array}$ & $\begin{array}{c}\text { Presentase } \\
(\%)\end{array}$ \\
\hline 1 & Mengurus Rumah Tangga & 12 & 80.0 \\
2 & Pegawai Negeri Sipil & 2 & 13.3 \\
3 & Karyawan Swasta & 1 & 6.7 \\
& Jumlah & 15 & 100 \\
\hline
\end{tabular}

Berdasarkan data jenis pekerjaan dapat diketahui bahwa sebanyak $80.0 \%$ adalah kelompok mitra yang aktivitas kegiatan sehari-hari mengurus rumah tangga dan lebih sering menggunakan peralatan yang memiliki resiko terhadap terjadinya bahaya kebakaran. Sedangkan kelompok mitra yang lain adalah warga masyarakat yang lebih banyak melakukan aktifitas dilingkungan kerja, kelompok mitra ini masih memiliki keterkaitan dengan potensi bahaya kebakaran yang berasal dari bahaya listrik maupun penggunaan peralatan yang memiliki resiko terhadap terjadinya bahaya kebakaran.

Hasil jawaban kuesioner yang sudah diisi oleh mitra untuk pertanyaan no. 1 sampai no. 4 digunakan untuk mengukur evaluasi berdasarkan aspek evaluasi proses pada tabel berikut:

Tabel 4. Hasil kuesioner aspek evaluasi proses

\begin{tabular}{|c|c|c|c|}
\hline \multirow{2}{*}{ No } & \multirow{2}{*}{ Materi pertanyaan } & \multicolumn{2}{|c|}{ Jawaban } \\
\hline & & Ya & Tidak \\
\hline 1 & $\begin{array}{l}\text { Keinginan untuk mempelajari } \\
\text { materi pelatihan }\end{array}$ & $100 \%$ & 0 \\
\hline 2 & $\begin{array}{l}\text { Pemahaman terhadap materi } \\
\text { pelatihan }\end{array}$ & $100 \%$ & 0 \\
\hline 3 & $\begin{array}{l}\text { Metode penyampaian kegiatan } \\
\text { pelatihan }\end{array}$ & $100 \%$ & 0 \\
\hline 4 & $\begin{array}{l}\text { Simulasi kebakaran sesuai } \\
\text { dengan jenis bahava di rumah }\end{array}$ & $100 \%$ & 0 \\
\hline
\end{tabular}


Berdasarkan hasil kuesiner dari aspek evaluasi proses mendapatkan sebanyak $100 \%$ mitra memberikan jawaban ya, hasil ini mengindikasikan bahwa materi pelatihan mendapatkan respon yang positif dari mitra yang mempunyai keinginan untuk mempelajari materi pelatihan pencegahan kebakaran sebagai langkah tindakan preventif untuk mengurangi resiko bahaya kebakaran di lingkungan rumah. Metode penyampaian materi pelatihan secara teori dan praktek sehingga dapat memudahkan dalam memahami materi, dengan demikian pelatihan yang disampaikan sudah sesuai dengan tujuan dan sasaran program pelatihan. Pelaksanaan kegiatan praktek memadamkan api sudah tepat sesuai dengan jenis bahaya kebakaran yang ada dalam lingkungan rumah.

Hasil jawaban kuesioner untuk pertanyaan no. 5 dan no. 6 digunakan untuk mengukur evaluasi berdasarkan aspek evaluasi hasil pada tabel berikut:

Tabel 5. Hasil kuesioner aspek evaluasi hasil

\begin{tabular}{cccc}
\hline \multirow{2}{*}{ No } & \multicolumn{2}{c}{ Materi pertanyaan } & \multicolumn{2}{c}{ Jawaban } \\
Ya & Tidak \\
\hline 5 & $\begin{array}{l}\text { Setelah mengikuti pelatiahan, } \\
\text { dapat mengetahui jenis bahaya }\end{array}$ & & \\
kebakaran disekitar rumah & & \\
6 & $\begin{array}{l}\text { Setelah mengikuti pelatiahan, } \\
\text { dapat memiliki keterampilan } \\
\text { untuk pencegahan kebakaran } \\
\text { di sekitar rumah }\end{array}$ & \\
\hline
\end{tabular}

Berdasarkan hasil kuesiner dari aspek evaluasi hasil mendapatkan sebanyak $100 \%$ mitra memberikan jawaban ya, hasil ini mengindikasikan bahwa setelah mengikuti kegiatan pelatihan, mitra mendapatkan ilmu pengetahuan dan menambah wawasan terkait penanggulangan kebakaran, sehingga dapat mendorong mitra untuk melakukan identifikasi potensi bahaya kebakaran yang berasal dari benda atau peralatan yang ada di sekitar rumah. Setelah mengikuti kegiatan pelatihan mitra merasakan ada penambahan hal yang positif dengan memiliki keterampilan untuk pencegahan kebakaran di sekitar rumah, sehingga dapat mendorong adanya kepedulian dari mitra untuk melakukan tindakan pencegahan kebakaran dalam komunitas lingkungan masyarakat serta dapat menumbuhkan sikap kesiapsiagaan terhadap bahaya kebakaran.
Hasil jawaban kuesioner untuk pertanyaan no. 7 sampai no. 9 digunakan untuk mengukur evaluasi berdasarkan aspek evaluasi dampak pada tabel berikut:

Tabel 6. Hasil kuesioner aspek evaluasi dampak

\begin{tabular}{|c|c|c|c|}
\hline \multirow{2}{*}{ No } & \multirow{2}{*}{ Materi pertanyaan } & \multicolumn{2}{|c|}{ Jawaban } \\
\hline & & $\mathrm{Ya}$ & Tidak \\
\hline 7 & $\begin{array}{lr}\text { Apakah bapak / ibu sudah } \\
\text { mempraktekkan } & \text { materi } \\
\text { pelatihan } & \text { pencegahan } \\
\text { kebakaran dalam kehidupan } \\
\text { sehari-hari? }\end{array}$ & $60 \%$ & $40 \%$ \\
\hline 8 & $\begin{array}{l}\text { Apakah bapak / ibu sudah } \\
\text { melakukan tindakan } \\
\text { pencegahan terhadap bahaya } \\
\text { kebakaran dalam kegiatan } \\
\text { memasak di dapur? }\end{array}$ & $100 \%$ & 0 \\
\hline 9 & $\begin{array}{l}\text { Apakah bapak / ibu sudah } \\
\text { memiliki alat pencegahan } \\
\text { kebakaran dirumah, misalnya } \\
\text { APAR, karung goni, dll ? }\end{array}$ & $53.3 \%$ & $46.7 \%$ \\
\hline
\end{tabular}

Berdasarkan hasil kuesiner dari aspek evaluasi dampak untuk pertanyaan no. 7 mendapatkan sebanyak $60 \%$ mitra memberikan jawaban ya, hasil ini dapat mengindikasikan bahwa kelompok mitra ini sudah mempraktekkan materi yang diperoleh dari kegiatan pelatihan sebagai salah satu dampak hasil pelatihan yang dapat memberikan dorongan untuk melakukan tindakan secara aman dan menumbuhkan sikap kepedulian terhadap bahaya kebakaran di lingkungan rumah. Respon dari mitra yang lain mendapatkan sebanyak $40 \%$ memberikan jawaban tidak, hasil ini dapat mengindikasikan bahwa kelompok mitra ini masih belum mencoba menerapkan materi perlatihan karena faktor kesibukan mengurus pekerjaan yang lain.

Hasil kuesioner untuk pertanyaan no. 8 mendapatkan sebanyak $100 \%$ mitra memberikan jawaban ya, hasil ini dapat mengindikasikan bahwa kegiatan memasak di dapur merupakan kegiatan rutin setiap hari, sehingga mitra menganggap hal yang penting untuk melakukan tindakan pencegahan terhadap potensi bahaya kebakaran. Hasil kuesiner untuk pertanyaan no.9 mendapatkan sebanyak 53.3 $\%$ mitra memberikan jawaban ya, hasil ini dapat 
mengindikasikan bahwa mitra dalam kelompok ini sudah mempunyai tingkat kesadaran dan kepedulian secara mandiri dalam menghadapi kebakaran dengan menyiapkan peralatan pencegahan kebakaran dilingkungan rumah terutama untuk menjaga harta benda dan keselamatan nyawa. Respon dari mitra yang lain mendapatkan hasil sebanyak $46.7 \%$ memberikan jawaban tidak, hasil ini dapat mengindikasikan bahwa kelompok mitra ini masih belum mempunyai pandangan bahwa ketersediaan peralatan pencegahan kebakaran dirumah merupakan langkah tindakan pencegahan untuk meminimalisasi faktor penyebab yang dapat menimbulkan bahaya kebakaran.

Dalam kuesioner disediakan 1 pertanyaan terbuka berupa saran atau masukan untuk kegiatan pelatihan pencegahan kebakaran. Beberapa saran dan umpan balik yang diberikan oleh mitra yaitu lebih banyak membuka sesi tanya jawab, kegiatan pelatihan dibuat lebih menarik dan diperbanyak pada bagian praktek, pelatihan perlu dilakukan secara berkala supaya lebih jelas, kegiatan pelatihan perlu ditambahkan dengan materi lain yang relevan agar pemahaman yang lebih jelas, perlu menambah kegiatan sosialisasi dengan pemberian pamflet mengenai informasi APAR (alat pemadam api ringan), pelatihan pencegahan kebakaran perlu terus dilakukan kepada masyarakat agar masyarakat dapat memahami, persiapan pelatihan lebih dimatangkan lagi dan tempat yang lebih memadai untuk kegiatan praktek memadamkan api disesuaikan dengan jumlah peserta yang hadir mengikuti pelatihan.

Hasil aspek evaluasi proses terhadap kegiatan pelatihan pencegahan kebakaran yang sudah dilakukan mulai tahap persiapan, penyampaian materi sampai pelaksanaan kegiatan praktek dapat dinyatakan sudah berjalan dengan baik sesuai dengan tujuan dan sasaran program pelatihan yang akan dicapai. Mitra memberikan respon yang positif dengan terlibat secara aktif dalam kegiatan pelatihan dan sebagai besar mitra menyatakan mempunyai keinginan untuk mempelajari materi pelatihan pencegahan kebakaran. Metode pelaksanaan kegiatan pelatihan yang disampaikan secara teori dan praktek, sehingga dapat menarik minat belajar dan tidak membosankan. Pelaksanaan kegiatan praktek memadamkan api sudah sesuai dengan jenis bahaya kebakaran dalam lingkungan sekitar rumah.
Aspek evaluasi proses yang masih perlu dilakukan perbaikan berdasarkan saran dan masukan yang diberikan oleh mitra yaitu persiapan kegiatan pelatihan perlu direncanakan dengan lebih baik, yang berkaitan dengan materi, peralatan dan perlengkapan dalam kegiatan praktek serta ketersediaan tempat sesuai dengan jumlah peserta yang akan hadir. Dalam penjelasan materi lebih banyak memberikan kesempatan untuk sesi tanya jawab, sehingga materi yang masih belum bisa dipahami atau masih belum jelas dapat ditanya untuk memperoleh penjelasan materi secara lebih detail. Kegiatan pelatihan dibuat lebih menarik sehingga dapat mendorong semangat mitra untuk dapat mengikuti seluruh kegiatan pelatihan. Pelatihan dalam bagian praktek lebih diperbanyak, karena melalui kegiatan praktek materi dapat melekat kuat dalam ingatan berdasarkan pegalaman selama mengikuti kegiatan pelatihan.

Hasil aspek evaluasi hasil terhadap kegiatan pelatihan pencegahan kebakaran yang sudah dilakukan dapat diketahui bahwa pelaksanaan program pelatihan pencegahan dan penanggulangan kebakaran di lingkungan rumah tangga yang sudah dilakukan dapat dinyatakan bahwa kegiatan pelatihan dapat mendorong sikap kepedulian mitra untuk melakukan tindakan pencegahan kebakaran. Kegiatan pelatihan dapat mendorong mitra untuk melakukan identifikasi potensi bahaya kebakaran yang berasal dari peralatan yang ada di rumah seperti peralatan listrik, peralatan elektronik dan penggunaan kompor gas.

Perubahan yang dapat dilihat dari aspek evaluasi hasil dengan adanya respon positif yang sudah ditunjukkan oleh mitra yaitu sikap kepedulian untuk melakukan tindakan pencegahan kebakaran dalam komunitas lingkungan masyarakat dan sikap kesiapsiagaan atau tanggap darurat terhadap potensi bahaya kebakaran. Hasil kegiatan pelatihan yang dapat dirasakan oleh mitra yaitu mendapatkan ilmu pengetahuan dan menambah wawasan tentang penanggulangan kebakaran dan memiliki keterampilan dalam tindalan pencegahan kebakaran di lingkungan rumah.

Hasil aspek evaluasi dampak terhadap kegiatan pelatihan pencegahan kebakaran yang sudah dilakukan dapat diketahui bahwa pelaksanaan program pelatihan dapat memberikan dorongan

Lingkungan Hidup dan Kebencanaan 476 
perubahan positif dari mitra yang sudah mempraktekkan materi yang diperoleh dari kegiatan pelatihan dengan melakukan tindakan secara aman dan mengetahui potensi bahaya yang dapat menyebabkan terjadinya kebakaran dari peralatan memasak seperti melakukan pemeriksaan secara rutin pemasangan regulator tabung yang berpotensi mengakibatkan terjadinya kebocoran gas dari tabung elpiji. Mitra sudah memiliki sikap kepedulian dalam menghadapi bahaya kebakaran dengan menyiapkan peralatan pencegahan kebakaran dilingkungan rumah terutama untuk menjaga harta benda dan keselamatan nyawa. Tingkat kesadaran yang sudah ditunjukkan mitra dengan melakukan tindakan aman dalam aktivitas kegiatan sehari-hari di lingkungan rumah.

Berdasarkan hasil evaluasi yang sudah diperoleh berdasarkan aspek evaluasi proses, evaluasi hasil dan evaluasi dampak, maka dapat dibuat keputusan bahwa kegiatan pelatihan dalam program pengabdian kepada masyarakat yang dilakukan team dosen Teknik Industri UMJ dapat dinyatakan masih diperlukan keberlanjutan dengan beberapa aspek yang perlu mendapatkan perbaikan untuk meningkatkan kualitas program pelatihan yaitu kegiatan pelatihan dapat dilanjutkan dengan menambahkan materi lain yang relevan sesuai dengan situasi dan kondisi yang dibutuhkan warga masyarakat sehingga mitra mendapatkan pengetahuan dan pemahaman materi yang lebih luas dan secara mendetail. Kegiatan pelatihan perlu dilakukan dengan mengadakan penyuluhan dalam periode waktu secara rutin sehingga dapat mengembangkan potensi dan kemampuan yang ada di warga masyarakat. Kegiatan pelatihan dapat dilakukan melalui sosialisasi dengan pemberian pamflet atau metode yang lain yang lebih relevan untuk menyampaikan informasi atau hal-hal yang penting untuk diketahui oleh warga masyarakat sebagai bentuk kepedulian dan aksi nyata pengabdian dari kalangan akademis.

Dampak dari program pelatihan bagi mitra yaitu dapat memberikan dorongan untuk melakukan tindakan secara aman terhadap bahaya kebakaran yang ada dilingkungan rumah. Mitra sudah memiliki sikap kepedulian dalam menghadapi kebakaran dengan menyiapkan berbagai peralatan pencegahan kebakaran untuk menghilangkan kemungkinan terjadinya kebakaran terutama untuk menjaga harta benda dan keselamatan nyawa.
Hasil analisis situasi dan kondisi lokasi lingkungan mitra dapat diketahui bahwa kelemahan dalam pencegahan kebakaran yaitu jalur akses ke lokasi mitra sangat sempit dengan akses jalan masuk yang hanya jalan gang yang kecil sehingga akan menyulitkan akses mobil pemadam kebakaran dan lokasi mitra tidak memiliki alat pemadam kebakaran berupa hydrant yang berfungsi untuk memadamkan kebakaran secara efektif dalam waktu yang singkat. Penataan lingkungan rumah di lokasi mitra dengan jarak antar bangunan sangat berdekatan dan jumlah penduduk yang cukup padat.

Tindak lanjut kegiatan program pengabdian kepada masyarakat untuk menyelesaikan masalah kebakaran dilokasi mitra yaitu dengan memberikan usulan atau masukan kepada mitra untuk mengaplikasikan kepemilikan APAR (Alat Pemadam Api Ringan) di rumah. APAR banyak digunakan sebagai alat proteksi kebakaran pada lingkungan rumah karena ukurannya kecil dan sangat ringan, sehingga dapat dibawa kemanamana. Jenis APAR yang dapat digunakan oleh mitra adalah jenis busa yang terdiri dari bahan kimia yang dapat membentuk busa AFFF (Aqueous Film Forming Foam) yang disembur keluar untuk menyelimuti material yang terbakar dan memutus keberadaan oksigen dalam lingkungan sekitar material sehingga api dapat cepat padam. APAR jenis busa AFFF dapat digunakan untuk kebakaran yang disebabkan dari material padat yang bukan logan seperti kertas, kain dan karet (kebakaran kelas A) dan kebakaran dari bahan cair seperti alkohol, solvent, minyak dan solar (kebakaran jenis B).

\section{KESIMPULAN}

Berdasarkan hasil analisis data dan pembahasan, dapat dibuat kesimpulan, yaitu :

1. Aspek evaluasi proses pelatihan dapat diketahui bahwa pelatihan sudah dibuat secara menarik dengan metode pelaksanaan kegiatan pelatihan yang disampaikan secara teori dan praktek. Kegiatan pelatihan mendapatkan respon yang positif dari mitra yang mempunyai keinginan untuk mempelajari materi pelatihan pencegahan kebakaran, sehingga dapat dinyatakan bahwa kegiatan pelatihan sudah sesuai dengan tujuan dan sasaran program yang sudah ditetapkan.

2. Aspek evaluasi hasil pelatihan dapat diketahui bahwa kegiatan pelatihan dapat mendorong

Lingkungan Hidup dan Kebencanaan

477 
kepedulian mitra untuk melakukan tindakan pencegahan kebakaran dengan melakukan identifikasi potensi bahaya kebakaran yang berasal dari peralatan yang ada di sekitar rumah. Hasil pelatihan dapat mendorong kepedulian mitra untuk melakukan tindakan pencegahan kebakaran dalam komunitas lingkungan masyarakat dan menumbuhkan sikap kesiapsiagaan terhadap bahaya kebakaran.

3. Aspek evaluasi dampak pelatihan dapat diketahui bahwa kegiatan pelatihan memberikan perubahan positif bagi mitra dengan mempraktekkan materi yang diperoleh dari kegiatan pelatihan dan mitra dapat mengetahui potensi bahaya kebakaran. Mitra sudah memiliki sikap kepedulian dan tanggap darurat dalam menghadapi kebakaran dengan menyiapkan peralatan pencegahan kebakaran untuk memperkecil dampak kerugian yang timbulkan.

\section{UCAPAN TERIMAKASIH}

Ucapan terima kasih yang tulus dipersembahkan kepada Lembaga Penelitian dan Pengabdian kepada Masyarakat (LPPM) Universitas Muhammadiyah Jakarta, sesuai dengan kontrak nomor : 75/R-UMJ/VII/2020, tanggal 9 Juli 2020.

\section{REFERENSI}

Amat Rahmat, dkk (2018). Studi evaluasi model bentuk atap dan fenomena kebakaran penyebab listrik pada rumah tinggal menengah ke bawah di pemukiman padat. Jurnal Arsitektur Zonasi, vol.1, no.2, h.112-122.

Anwas, Oos M. 2014. Pemberdayaan masyarakat di era global. Bandung: Alfabeta.

Dedi, M (2009). Pedoman evaluasi dan indikator kinerja pembangunan. Kedeputian evaluasi kinerja pembangunan badan perencanaan pembangunan nasional.

Dewi Kurniawati, 2013, Taktis memahami keselamatan dan kesehatan kerja, Surakarta : PT Aksara Sinergi Media.

Eni Supartini, dkk. (2017). Membangun kesadaran, kewaspadaan dan kesiapsiagaan dalam menghadapi bencana. Buku pedoman Latihan kesiapsiagaan bencana. Jakarta : BNPB.

Furi Sari Nurwulandari. (2012). Kajian kemampuan masyarakat di permukiman padat dalam mitigasi kebakaran ( studi kasus : Kelurahan Taman Sari, Kota Bandung ). Tesis Program Studi Magister Perencanaan Wilayah dan Kota. Institut Teknologi Bandung.

Hidayat, D.A., Suroto., Kurniawan, B. (2017). Evaluasi keandalan sistem proteksi kebakaran ditinjau dari sarana penyelamatam dan sistem proteksi pasif kebakaran di gedung Lawang Sewu Semarang. Jurnal Kesmas, 5(5): 134-145.

Michael, P. (2006). Metode Evaluasi Kualitatif. Semarang : Pustaka Pelajar.

Irfanul, Muhamad Hadi, dkk (2019). Implementasi sistem real time peringatan kebakaran pada terminal listrik rumah tangga. Jurnal Pengembangan Teknologi Informasi dan Ilmu Komputer. vol.3, no.2, h. 2036-2042.

Ramli, Soehatman (2010). Manajemen kebakaran. Jakarta : Dian Rakyat.

Ranti Hidayawanti (2018). Upaya tertib listrik terhadap instalatir kabel di daerah padat penduduk (study kasus kec. Tambora). Jurnal Kilat vol.7, no.1, h. 24-29.

Sucipto, 2014, Keselamatan dan kesehatan kerja. Yogyakarta : Gosyen Publishing.

Sugiyono. (2013). Metode Penelitian Pendidikan, Pendekatan Kuantitatif, Kualitatif, dan R\&D. Bandung: Alfabeta.

Tini, dkk (2015). Analisis kebijakan pemantauan dan evaluasi dalam upaya penyusunan instrumen pemantauan dan evaluasi program jaminan kesehatan nasional. Kementerian koordinator bidang pembangunan manusia dan kebudayaan.

United Nations Development Programme. (2009). Handbook on Planning, Monitoring and Evaluating for Development Result. New York : A.K. Office Supplies.

Yunita Adilla, dkk (2016). Faktor penyebab kerentanan kebakaran berdasarkan persepsi masyarakat di kelurahan Melayu kecamatan Banjarmasin Tengah. Jurnal Pendidikan Geografi. vol. 3, No 4, h. 40-57.

www.jakartafire.net/statistic

Lingkungan Hidup dan Kebencanaan 478 